\title{
La confiança en l'alimentació dins les societats modernes
}

\author{
Javier Callejo
}

Departamento de Sociología I: Teoría, Metodologia y Cambio Social de la UNED

mcallejo@poli.uned.es

Rebut: 10-04-2008

Acceptat: 11-03-2009

\section{Resum}

L'article que es desenvolupa a continuació té com a finalitat principal mostrar la connexió entre una àmplia vivència en clau del risc experimentat en relació amb el menjar dins les societats occidentals $i$, alhora, un marc general de confiança dels diferents agents i institucions (administracions públiques, indústria, distribuïdors, experts, etc.) que treballen en el consum alimentari. A partir d'aquí, s'intenta respondre una pregunta: com es genera la confiança en l'alimentació dins les societats modernes? Malgrat l'eterna por humana vers el menjar, l'augment constant de nous productes desconeguts per la pròpia cultura i les repetides crisis alimentàries, el consumidor confia i recupera contínuament la confiança. És a dir, malgrat l'augment de la sensació de risc, hi ha una confiança general. Així doncs, s'intenta reflexionar sobre les característiques d'aquest procés de confiança $\mathrm{i}$, especialment, sobre el procés de recuperar-la.

Paraules clau: confiança social, crisis alimentàries, sociologia del risc.

\section{Abstract: The confidence in food in modern societies}

The main goal of this article is to demonstrate the link between the widely experienced risk related to food in Western societies and, at the same time, a broad confidence in the various players and institutions of food consumption (government, industry, distributors, experts, etc.). Thereafter, the article tries to answer the question: how is confidence in food generated in modern societies? Despite the eternal fear concerning human food, the constant increase of new products unknown to one's own culture and recurrent food crises, the consumer confides and continuously recovers confidence, which means that although the sensation of risk increases, there is some general confidence. Therefore, the intention is to reflect on the characteristics of this confidence process, and especially about the process of recovering it.

Key words: social confidence, food crises, risk sociology. 


\begin{aligned} & \multicolumn{2}{c}{ Sumari } \\ & Introducció La confiança i les crisis alimentàries \\ & El risc del menjar Conclusions \\ & La doble concreció de la confiança Referències bibliogràfiques \end{aligned}

\section{Introducció}

La seguretat s'ha convertit aparentment en la categoria central de les nostres societats, tal com abans ho van ser possiblement la conquesta del món o la revolució. De fet, el risc s'ha situat al centre dels debats sociològics (Beck, 1992; Giddens, 1990; Luhmann, 1992; Le Breton, 1995) com l'altra cara de la seguretat. Hi ha una redefinició dels problemes socials en termes de seguretat (Wacquant, 2000: 70). Potser és per això que cada vegada que es produeix un esdeveniment que posa de manifest la debilitat d'una seguretat que es considerava gairebé aconseguida del tot, es posa a tremolar el món social en què vivim i sorgeixen respostes socials que adopten la forma del pànic. Això passa especialment quan l'esdeveniment està protagonitzat per accions, en lloc d'estar originat en la naturalesa de l'ésser humà, és clar. Va succeir amb la catàstrofe de Txernòbil i amb els atemptats de l'11-S. També succeeix amb cadascuna de les crisis sanitàries relacionades amb el consum de menjar, quan tot el vincle amb el sistema alimentari trontolla com en un terratrèmol. Tanmateix, cal subratllar que la relació entre seguretat i alimentació ve de lluny.

Des dels orígens de l'home, l'alimentació ha estat la preocupació principal de les societats. La majoria de comportaments de les comunitats humanes, com a ens col-lectius, tenen origen en aquesta preocupació (Harris, 1999). Ara bé, el centre d'atenció ha estat la quantitat de menjar.

Una quantitat que, en els cicles que anava seguint, es podia projectar sobre l'evolució demogràfica, com va fer Malthus (1990) amb una doctrina sobre l'escassetat, i que, en tot cas, era un factor determinant dels moviments (estades, migracions) i les regulacions (infanticidi, guerres) d'aquestes societats. De fet, actualment, el concepte de seguretat alimentària s'utilitza als països en vies de desenvolupament com un conjunt d'actuacions i de polítiques per tal d'evitar les crisis d'escassetat de menjar. La seguretat dels aliments consistia -i encara continua consistint - a garantir-ne la quantitat per a una població determinada.

Tanmateix, fa pràcticament cent anys que la major part dels països occidentals ha deixat enrere els problemes de patir gana. Llevat de les crisis alimentàries provocades per esdeveniments com ara les guerres, externs a la pròpia producció de menjar, Occident sembla que ha assolit aquesta seguretat quantitativa durant el segle XX. Aquesta circumstància es veu reflectida a Espanya, ja que, amb l'excepció de la fam que es va passar durant la guerra i la postguerra civil en algunes localitats, especialment a les concentracions urbanes, amb prou feines hi ha hagut problemes greus de manca d'aliments durant 
el segle passat. La possibilitat de menjar alguna cosa ha estat pràcticament assegurada per al conjunt de la població.

Entre les solucions als problemes d'escassetat, hi ha una intensificació de la producció gràcies a l'aplicació de noves tècniques d'explotació agrícola i ramadera. No es poden deixar de banda uns altres aspectes, com ara la conformació de mercats cada vegada més grans que faciliten els fluxos d'intercanvi dins d'una creixent divisió internacional de la producció, així com els contactes amb fonts subministradores d'aliments; o la introducció de polítiques que regulen les quantitats produïdes i els preus en els casos més concrets de mercats locals. Tot i ser conscients de la solució relativament satisfactòria dels problemes de seguretat quantitativa dels aliments, costa esborrar de la nostra cultura la llarga història passada. Potser fins i tot del nostre propi cos. Molts de nosaltres ens enfrontem a resistències anímiques a l'hora de decidir què fem amb el menjar que sobra. Experimentem un sentiment especial quan es llencen trossos de pa a les escombraries i intentem que els nostres fills valorin el plat que tenen davant. Per tal d'animar-los a menjar, els expliquem històries sobre la fam que pateixen uns altres nens. Són empremtes patents del passat. Potser mecanismes d'estalvi davant els temors incerts del futur. Avui el menjar està assegurat i demà sembla que també. Mirem el demà passat amb temor inconscient?

A més de la seguretat d'existència d'aliments, s'estableix un altre tipus de seguretat, la que està relacionada amb les conseqüències sanitàries d'allò que es menja. La preocupació no se centra en les possibilitats de menjar, sinó en les conseqüències que comporta fer-ho ${ }^{1}$. Estem segurs que els aliments de què disposem són beneficiosos o que, almenys, no suposen cap dany per a la salut? La resposta a aquesta pregunta dependrà de la societat a la qual es formuli, tenint en compte la relació del consumidor potencial i el producte de consum potencial en aquesta societat. Si és un aliment conegut pel consumidor, perquè tots dos pertanyen al mateix col-lectiu, el grau de seguretat que se sent té força possibilitats d'augmentar. És possible que la ingesta ni tan sols s'experimenti com un risc acceptat, ja que el risc que s'assumeix és molt baix, sobretot quan es tracta d'una societat que, com la majoria de les avançades, s'instal.la en un context en què la confiança n'és una institució central. Encara més, com veurem, l'establiment de la confiança en una institució central obre les portes a productes nous, abans parcialment o totalment desconeguts pels comensals, tot i que cal reconèixer que el màrqueting ajuda notablement a convertir el producte desconegut en conegut.

El procés civilitzador (Elias, 1989) emprès inicialment a Xina i Europa occidental, i projectat posteriorment als països de domini cultural europeu, ha derivat en un sistema d'higiene general, introduït pels seus individus, que ha centrat l'atenció principal en el tractament dels aliments, incloent-ne la fase

1. Aquesta és l'accepció de seguretat alimentària als països desenvolupats reconeguda institucionalment, que dóna pas a la creació de les agències de seguretat alimentària als Estats Units, a la Unió Europea i a d'altres països. 
de producció. D’altra banda, seguint el propi Norbert Elias, pot dir-se que el procés civilitzador al qual s'incorpora aquest sistema d'higiene, a més d'una visió científica a l'hora de fer front a les epidèmies, es produeix principalment en l'acte de menjar i el sistema de contactes que implica el menjar, amb el comensal i entre comensals. El sistema d'higiene i prevenció s'estén especialment amb el certificat públic. Tampoc no se'n poden excloure uns altres canvis socials susceptibles d'ésser integrats al propi procés civilitzador, com una certa homogeneïtzació inicial de la dieta aplicada sobre els aliments que es consideren segurs, excloent-ne alhora aquells que es conceben com a menys segurs; o bé, en relació amb l'anterior, com el reforç de la selecció dels aliments en purs i impurs a partir de l'extensió de l'ètica protestant ${ }^{2}$.

D'aquesta manera, durant la major part del segle XX, el consumidor occidental semblava que vivia segur, en una relació de baix risc amb els aliments. $\mathrm{Si}$ ens fixem en els processos objectius, cal reconèixer que els trastorns sanitaris més o menys immediats produïts per ingestes, més aviat han constituït un esdeveniment relativament estrany i molt localitzat, recollits com a notícia pels mitjans de comunicació, que no pas una evocació constant al món econòmicament ric. Encara que també cal tenir en compte que la solució sanitària d'aquests trastorns fou més ràpida i eficaç en societats amb sistemes sanitaris $\mathrm{i}$ hospitalaris desenvolupats, aparentment domina la seguretat. Hi ha una confiança en el sistema alimentari que es podria qualificar de pràcticament immediata, que amb prou feines es posa en qüestió durant la pràctica quotidiana. Els riscos ${ }^{3}$ semblen relativament febles, tal com s'encarreguen de repetir les autoritats públiques després de cada esdeveniment relacionat amb el menjar i la sanitat.

Aquests riscos fan referència fonamentalment a la circumstància estadística de perdre la vida o de caure greument malalt a causa del consum d'un únic producte. Els perills deriven principalment d'ingestes continuades, de dietes a llarg termini, però no a curt termini i per ingestes aillades. Sobre aquesta projecció del risc alimentari a llarg termini, hi reposa una bona part del caràcter diferencial de la confiança moderna en els aliments. El risc principal i dominant queda reduït al llarg termini ${ }^{4}$. Vol dir això que la por relacionada amb

2. Potser això explica per què les llistes de zones geogràfiques que exclouen més aliments (rates, insectes, etc.) estan encapçalades pels països occidentals, en general, i pels de domini de la religió protestant, en particular. Vegeu el quadre presentat per Fischler (1995: 30), on la llista de productes no comestibles és més nombrós i comú a l'Amèrica del Nord i al centre d'Europa.

3. En aquest treball, s’entén el risc com una dimensió subjectiva. És una percepció de risc vinculada a decisions. Decisions que són dels subjectes i que, per tant, es poden concebre com a risc subjectiu, de percepció; fins i tot quan la perspectiva de Luhmann (1992), dominant en aquest context i sempre paradoxal, és estranya a la idea de subjecte. D'altra banda, el concepte de perill condueix directament a condicions donades que podríem qualificar d'objectives. És per això que, entre altres coses, s'ha pogut introduir aquest concepte al codi penal.

4. Això no significa que abans no hi hagués perills a llarg termini de determinats tipus d'alimentació o dietes. La majoria d'aquests perills van ser descoberts després d'una llarga tradició de consumir-los. 
l'alimentació ha desaparegut i que menjar ja no comporta cap risc? Fins fa poc, amb prou feines es qüestionava aquest segon tipus de seguretat. Vegem-ne un exemple: en els diversos textos, manuals i col-leccions d'assaigs sobre sociologia de l'alimentació escrits fa més de deu anys, es parla de menús, de llenguatges culinaris, de canvis d'hàbits o d'estils a la taula; però no hi ha referències a la seguretat ni al risc. A l'actualitat, les prestatgeries de novetats sobre el tema es distingeixen per la presència d'obres, escrites per metges, en les quals es posa en evidència la relació entre la salut i els aliments. En una societat obsessionada amb la seguretat, no n'hi ha mai prou, $i$ encara menys quan es tracta del menjar.

\section{El risc del menjar}

El menjar és font de vida. Més enllà del plaer que ens pugui causar, mengem per viure. Juntament amb dormir, és l'única pràctica imprescindible on es confonen la reproducció social i la reproducció fisiològica. Ara bé, menjar també pot provocar la mort. El refranyer n'és ple de referències. Només cal recordar la dita castellana que afirma: «De cenas copiosas, están las tumbas llenas», per assenyalar que les conseqüències dels àpats excessius són tan temudes com les de l'absència o escassetat d'aliments. En abundància, el menjar també pot ser mortal. Aquesta sospita sobre l'alimentació ha fet que, encara que puguem ingerir tota mena d'aliments, s'extremin els dispositius de selecció sobre el que es menja, si tenim en compte que, dins de cada cultura, la quantitat d'allò que renunciem a menjar és molt més elevada, tot i ser admissible per l'organisme humà, que la quantitat del que ingerim. Hi ha una relació antropològica de desconfiança en el menjar que crea una tendència a preferir el que ens és conegut, tot i que s'hagin anat produint canvis en la nostra dieta. És més, des de l'exclusiva perspectiva del risc alimentari, la pregunta important no és per què consumim el que consumim, sinó quins mecanismes socials actuen perquè es deixin de consumir productes dels quals podem disposar facilment i que són ben assequibles.

Tal com han posat de relleu els antropòlegs, la desconfiança ha acompanyat el plaer de menjar durant gairebé tota la història de l'ésser humà. Només l'individu occidental del segle XX semblava que havia deixat de costat la perspectiva dels aliments com un problema. En tot cas, era un problema dels altres: altres cultures, altres països, civilitzacions anteriors. Com a màxim, un problema de l'individu occidental quan visitava aquestes altres cultures o països. Actualment, el plaer de menjar està menys vinculat a la desconfiança, tot i que no es pot donar per desapareguda. L’omnívor sempre desconfia (Fischler, 1995).

Entrem així en el que, de forma molt encertada, Fischler denomina "paradoxa de l'omnívor»: l'obligació biològica d'ingerir alimentació variada i les restriccions culturals que ens empenyen a consumir només aliments coneguts, identificats i valorats. Una paradoxa que disposa de diverses actualitzacions, per exemple, la que proclama una alimentació equilibrada com a terme que comprèn la varietat racionalitzada, així com els estils de vida que seleccionen 
un conjunt relativament reduït d'aliments ben valorats. És com si el risc continués allà present — potser canviant-ne les formes_-, però amb una força que es fa palesa després de cadascuna de les crisis recents. Per aquestes raons que s'acaben d'exposar, actualment, menjar també comporta l'acceptació d'un risc i l'existència d'unes fonts de confiança. Com que hem de menjar, hem de confiar. Tal com apunta Luhmann (1979: 10), es confia per necessitat, no per elecció. Però es tracta d'una confiança que, com sempre, implica un risc. La confiança i l'acceptació del risc, conceptes aportats de forma pertinent per l'antropòloga Mary Douglas (1996), que els va introduir al sistema cultural, van juntes. L'acceptació subjectiva del risc va lligada amb la necessitat estructural i objectiva de confiança. Si no fos així, entendríem el menjar com una estressant ruleta russa, en la qual cada queixalada comportaria el risc de morir. I no és així com el concebem, ni com s'ha donat la tendència de viure en situacions que els comensals poden considerar quotidianes o normals des del punt de vista social.

Quan ens enfrontem a l'alimentació, el risc sembla que vagi més enllà del nostre temps, de la nostra anomenada "societat del risc», i sembla que sempre hagi estat allà, al costat del plaer que suposa gairebé sempre el simple fet de menjar; en definitiva, al costat de la concepció de l'alimentació com a font de vida.

De quin risc estem parlant quan ens referim a l'alimentació? A què ens arrisquem? Sembla que a la malaltia. Fins i tot a la mort. Com si després de cada queixalada hi hagués el final de la nostra existència. Davant d'aquesta aclaparadora afirmació, convé establir matisos i diferenciar els diferents tipus de risc. Utilitzaré el temps com a criteri diferenciador principal.

Existeix un risc a curt termini, que es manifesta com a reacció immediata a un àpat. Si no genera efecte fisiològic desagradable en el procés de metabolització de l'aliment concret, aquest risc es pot considerar superat. Contràriament, parlaríem de processos com ara intoxicacions, que és el mal més present al llarg de la història de l'alimentació, o fins i tot d'indigestions, passant per contagis més o menys pròxims, com és el cas de la salmonel.losi. Alguna cosa ens pot «fer mal». Antigament, en molts casos, comportava un risc de mort immediata. Actualment, un sistema de prevenció estès i la institucionalització dels controls veterinaris i sanitaris han convertit l'acceptació d'aquest risc en una qüestió relativament menor. No obstant això, continua sent el tipus de risc dominant en les crisis alimentàries de productes crus (salmonel.la, listèria, etc.).

Hi ha un risc a llarg termini bastant més difús que l'anterior, ja que només es manifesta amb el pas del temps, amb la ingesta repetida del mateix tipus d'aliment i gairebé sempre acompanyat d'altres circumstàncies, de manera que ni tan sols els estudis epidemiològics més rigorosos no són capaços d'establir una relació directa entre la causa i l'efecte, entre el que es menja i les conseqüències que comporta aquest fet. El risc a llarg termini apareix representat com a mort avançada o vida escurçada: menjar alguna cosa al llarg del temps pot minvar l'existència, generar malalties diverses, transformar el metabolisme fins arribar a produir una mort que pot considerar-se prematura. Així, es parla de la relació entre algunes dietes i el càncer. 
En aquest segon tipus de risc, ja no és l'aliment concret, l'estat del producte específic, el seu origen, sinó l'aliment com a dieta i, a diferència de l'anterior, es basa en productes cuinats com a part central d'un hàbit alimentari. És una segona concepció del risc que s'introdueix a la història amb la modernitat, gràcies a una medicina científica que, de forma experimental, cerca causes de certes malalties i les troba en determinats hàbits alimentaris i en un protagonisme més gran de la prevenció en el sistema ideològic, és a dir, amb l'assumpció que es pot actuar sobre la salut present i, sobretot, futura a partir de l'alimentació. Menjar ja no és només una font de vida i la potencial causa de la mort, sinó una font que allarga la vida o que ens acosta a la mort. D'aquesta manera, el risc queda estès al llarg del temps i el fet d'acceptar-lo s'acosta a una estrategia vital, on el grau d'informació i de coneixement sobre aquests riscs a llarg termini adquireix una rellevància especial. Vegem-ne un exemple. Gairebé ningú no dubta del bon estat sanitari de la major part dels productes catalogats com a fast food. Les marques principals especialitzades en aquest tipus d'alimentació (McDonald's, Burger King, Wendy) extremen els controls i els procediments d'higiene com a barrera de protecció de la marca. Tanmateix, el problema es planteja en la dieta. De fet, el llibre de Schlosser (2003), així com la pel-lícula que li dóna vida (Fast Food Nation), emfatitza la rutina, la repetició d'ingestes.

\section{La doble concreció de la confiança}

Tal com s'ha assenyalat, els dos tipus de risc han tingut un domini diferent al llarg de la història. També han tingut fonts de confiança diferents, molt necessàries per a aquesta acceptació del risc. Així doncs, es poden concretar models diversos del risc de menjar. Acceptar el risc no és el mateix que gestionar-lo, com diu Douglas (1996). Amb el menjar, gestionem progressivament el risc mitjançant dispositius de confiança que han variat al llarg dels temps. En un desig de síntesi explicativa que té com a objectiu realçar el moment en què ens trobem, ja que no es tracta d'un treball històric, es poden establir dos grans models (quadre 1).

D'una banda, trobem un model tradicional, que és el que ha ocupat la major part de l'existència humana i del qual encara queden trets en algunes parts del planeta. En aquestes societats tradicionals, el risc de menjar tendeix

Quadre 1. Models de concreció de la confiança

\begin{tabular}{lll}
\hline & Societats premodernes & Societats modernes \\
\hline Centre d'atenció de seguretat & Escassetat & Sistema de seguretat \\
Lògica & Quantitat & Qualitat \\
Font del risc & Ingesta & Dieta \\
Font de confiança & Pròpia experiència & Mediàtica \\
Marc & Local & Deslocalització \\
Gestió personal & Tàctiques & Estratègies \\
\hline
\end{tabular}


a trobar-se en el context del risc de no menjar, és a dir, de l'escassetat, fins i tot quan alguns antropòlegs, amb Shallins (1983) al capdavant, han assenyalat que aquesta imatge d'escassetat contínua és una projecció invertida de les societats desenvolupades i centrades en l'ètica de la feina, societats que treballen per satisfer les seves necessitats d'alimentació, de manera que fins i tot poden ser considerades societats d'abundància, si s'emfatitza el temps de desocupació «laboral» de què disposen i no tant els béns disponibles.

Independentment del debat, el model d'acceptació del risc referent a allò que mengem està dominat pel curt termini, per les repercussions immediates (Flandrin, 1998: 123), amb freqüència mortals, del que s'ingereix. Per això, hi hauria una tendència a reduir el risc a zero. Les conseqüències d'una ingesta inadequada són massa evidents i ja estan introduïdes en una racionalitat científica determinada. Fins i tot es pot parlar de certa aversió al risc alimentari, atesa la resistència d'aquest model a l'adopció de novetats. Cal tenir en compte que el dispositiu principal de confiança de què disposa és la tradició i la familiaritat amb els productes, és a dir, la pròpia experiència col-lectiva. D’aquesta manera, només es menja el que és culturalment reconegut, la qual cosa comporta una forta reducció de la varietat d'aliments ingerits, possiblement només transgredida en circumstàncies que són tant d'intensa escassetat de la dieta normal com de fam. És la necessitat més imperiosa de sobreviure la que porta a acceptar l'ampliació de la varietat del que es menja i, per tant, a acceptar el risc. Es confia en el que és conegut sense tenir consciència de confiança. Com s'ha esmentat més amunt, és una confiança basada en la familiaritat, perquè decideix més la cultura que no pas el propi individu. És per això que el marge del que denominem «acceptació del risc» és molt reduït. S'imposa la desconfiança i l'exclusió com a comestible del que no ha estat introduït en la cultura com a tal, d'allò culturalment localitzat, del que es troba dins el marc estrictament local, és a dir, l'alimentació i les solucions davant de les pertorbacions fisiològiques que genera, consideri's l'exemple de les plantes medicinals, que són radicalment locals.

En unes societats integrades en un món cultural més aferrat al passat que no pas al futur, el risc a llarg termini del que es menja pot considerar-se inexistent. Fins i tot hi ha una manca de la pròpia concepció de futur a llarg termini sense impregnació d'un pensament transcendent i religiós; així i tot, posteriorment, determinades dietes han demostrat que són perilloses. A la pràctica, el conjunt de la comunitat menja el mateix i les diferències entre els uns i els altres estan marcades pel plaer i la força immediata que dóna un tipus d'aliment i el que en dóna un altre. És clar que no és el mateix menjar carn, referent simbòlic occidental de la vitalitat alimentària tradicional, que sobreviure només a base de "pa i aigua", però era una diferència de plaer, per això la religió, a mesura que administrava els plaers i els sofriments en la vida terrenal, tenia tendència a intervenir-hi. Les diferències es projectaven més sobre la durada de la vida ultraterrenal, que no pas sobre la durada de la vida terrenal. Fins i tot, l'aliment més aviat podia fomentar la millora d'una malaltia apareguda, que no pas ser el motiu que aparegués per la repetició d'una dieta con- 
creta $^{5}$. Per això, prenent l'exemple del catolicisme, es van instituir les butlles per permetre als malalts que transgredissin una regulació alimentària religiosa, com és la prohibició de menjar carn durant alguns dies de quaresma.

En les societats modernes, s'instaura un altre model de gestió del risc que comporten els aliments. S'institucionalitza un sistema de control dels que arriben al consumidor, a més d'una extensió prèvia d'un sistema d'higiene, la qual cosa implica una profunda educació per part dels propis consumidors. D'aquesta manera, s'arriba a poder reconèixer l'estat (bo o dolent) del producte amb certa facilitat en la majoria dels casos, i es reserva el principi de precaució per al moment en què aquest reconeixement deixi de ser tan directe, com pot ocórrer amb determinats aliments dels anomenats "frescos», en els quals la possibilitat de control, malgrat que també s'hi projecta, sembla que tingui menys capacitat de normativització i estandardització.

En aquest model modern, el risc a curt termini sembla menor, gràcies a tota la vigilància pública. $S$ 'accepta el risc, fins i tot amb inclinació a provar la novetat, basant-se en altres fonts de confiança, com ara: $a$ ) les diferents institucions o organitzacions públiques i administratives destinades a vetllar pel bon estat dels aliments quan arriben al consumidor; $b$ ) la indústria agroalimentària a través de la marca, perquè aquesta constitueix una de les fonts de confiança principals en els aliments industrialitzats, amb una tendència a ser considerada com a "garantia» la que gaudeix d'un fort capital simbòlic; c) la mediació dels experts immediats, com són els que reconeixem com els «nostres» botiguers, carnissers, peixaters, fruiters, restauradors, etc., que, segons la lògica que exposa Adam Smith (1983), tendiran a vendre els seus productes en bon estat, no tant pel bé o per la satisfacció del consumidor, sinó pel seu propi bé, si volen continuar tenint una clientela fidel. Efectivament, el consumidor sol donar per fet que totes aquestes instàncies funcionen, especialment la instància $a$ o font abstracta i general de confiança, i deixa en una mesura més elevada $b$ i $c$, com a fonts nominals de confiança, a l'àmbit de la seva apreciació $\mathrm{i}$ elecció. És per això que, quan es produeix una crisi alimentària, com ara la de les «vaques boges» o els problemes amb les aus de procedència asiàtica, totes les mirades es dirigeixen cap a les autoritats públiques, principalment les estatals, a fi d'exigir-los responsabilitats, perquè es considera que tenen l'obligació de controlar el bon estat dels productes. Fins i tot quan s'aprecia que algun d'aquests mitjancers experts (peixaters, restauradors, etc.) no compleix degudament amb les garanties sanitàries, es responsabilitza les autoritats d'una falta de vigilància, d'un incompliment d'obligació, de la delegació pública i funcional de control, que està per sobre d'aquesta espècie d'autoregulació de mercat que es troba en els dispositius referits als punts $b$ i $c$.

Si el funcionament dels poders públics no respon a la confiança necessària dipositada, fa la impressió que es trenca tot el sistema de crèdit en els aliments

5. En aquest context, cal destacar la diferència amb l'actual lògica de medicalització de l'alimentació, quan certes dietes són destinades a prevenir malalties i no només a curar-les, com es concebia tradicionalment. 
que ens envolten. I és per això que la recomposició immediata d'aquest sistema i la recuperació d'autoritat, així com la seva funció com a font de garantia, són essencials, i es tracta d'una cosa que gairebé sempre es procura amb el suport de l'autoritat científica. Sol ser habitual que metges i científics donin instruccions sobre el comportament dels consumidors i emetin missatges de tranquil.litat destinats a rebaixar els nivells del que s'ha acabat denominant l'«alarma social». Si és una marca o un mitjancer expert qui traeix la confiança dipositada, és normal que quedi expulsat del mercat, ja sigui a causa de la intervenció de l'autoritat pública o bé per la pròpia lògica del mercat, ja que el consumidor s'inclinarà per altres marques o experts que li inspirin més confiança, és a dir, que li suposin un marge menor de risc acceptat. Tanmateix, com que no es tracta de l'únic element que es té en compte en el mercat, encara que en sigui un dels més importants, es torna a deixar en mans de les autoritats públiques la decisió sobre els límits segons els quals pot romandre a la venda una marca o pot continuar el seu negoci un expenedor d'aliments que pot arribar a posar en perill la salut. Cal tenir en compte que un preu atractiu i un màrqueting creatiu poden augmentar el marge d'acceptació de risc del consumidor. En tot cas, s'assumeix que l'obligació d'impedir que aliments que puguin tenir una repercussió negativa coneguda sobre el consumidor es puguin posar a la seva disposició recau sobre les autoritats públiques. El principi de seguretat s'imposa amb una àmplia legitimació, i és per això que, davant dels problemes sorgits, com ara les intoxicacions, les autoritats públiques apareixen com a responsables inicials, almenys fins que se n'assenyalen i se n'encausen els culpables directes, i gairebé sempre responsables subsidiaris quan els problemes són d'extrema gravetat, com va ocórrer amb la crisi generada a partir de l'oli de colza a Espanya. El consumidor només es converteix en víctima passiva.

Si, en el model modern, l'acceptació del risc alimentari s'estén en relació amb el risc a curt termini, ja que aquest és considerat menor, pràcticament mínim, el risc a llarg termini apareix, en canvi, amb una rellevància especial, amb la qual cosa canvia la ubicació del principal suport de la responsabilitat de l'acceptació d'aquest risc i de les fonts de confiança, en comparació amb l'acceptació del risc a curt termini. En el risc a curt termini, la responsabilitat es tendeix a projectar sobre les institucions i els agents institucionals. Per contra, en el risc a llarg termini, hi ha més marge per a la responsabilitat de l'individu dins d'un context amb un sistema de comunicació desenvolupat. S'estableix la possibilitat d'adoptar estratègies vitals, en la doble conformació de donar tant contingut i qualitat com quantitat i extensió a la vida a partir de la dieta. Majoritàriament, hi ha consciència que menjar de forma continuada algun tipus de producte que generi plaer i identitat, sempre que no existeixi una limitació mèdica explícita, pot tenir efectes a llarg termini. Es tracta d'uns tipus d'aliments que, alhora, sembla que donin sentit a la vida, al mateix temps que l'escurcen. En referència a l'alimentació, són comunes frases com ara: «Tot el que és bo, està prohibit», on «el que és bo» fa referència a productes que tenen un fort valor simbòlic dins de la cultura i que, en general, estan valorats per la societat, però sobre els quals cauen sospites dels efectes que produeixen a 
llarg termini si es mantenen en un lloc central de la dieta. Contràriament, unes altres dietes gaudeixen d'un extens suport per part de la literatura mèdica i nutricionista dels mitjans de comunicació com a font d'allargament de la vida $\mathrm{o}$, almenys, com a suficients per mantenir les forces, però sense les conseqüències negatives d'altres. Així, les dietes riques en fruites $i$, en general, en vegetals, gaudeixen d'un ampli prestigi en les societats occidentals. Cal destacar la important presència d'aquestes projeccions a llarg termini a l'hora d'acceptar el risc de l'alimentació en l'actualitat. Però, a més, s'ha d'assenyalar que l'acceptació del risc tendeix a ser concebuda com una tria individual o personal, com una selecció d'un estil de vida. I avui la nostra dieta no està fonamentada en la tradició, sinó en l'estil de vida, on el que és tradicional constitueix una de les possibles eleccions.

La dieta pot compondre's d'aliments de qualsevol lloc del món. Es pot parlar d'una deslocalització pràcticament total del seu origen. Els aliments es desvinculen de l'espai i del temps, ja que també podem tenir productes a taula que abans només es trobaven en plena temporada: tomàquets tot l'any, per exemple. La varietat als mercats i, sobretot, a les grans superfícies no deixa d'augmentar, cosa que fa que sembli que estem més a prop de l'horitzó de la concreció de l'home omnívor. Ara bé, cada elecció pot tenir conseqüències en el futur, ja sigui sobre el futur benestar físic 0 , directament, sobre la pròpia existència, però ara el màxim responsable és el propi consumidor o, a tot estirar, els mitjancers principals en el consum de grup (domèstic o col-lectiu), sempre que es disposi d'un marc consensuat d'informació especialitzada i d'un sistema autònom i desenvolupat de mitjans de comunicació ${ }^{6}$. Davant d'aquesta responsabilitat per part dels comensals, aquests estenen el seu comportament sobre una escala que té situat en un dels seus pols el consumidor disciplinat, fidel i estricte seguidor de les dietes que s'estableixen com a sanes o amb poc risc per a la salut futura. En termes de risc financer, podríem parlar d'un subjecte conservador. En aquest context, conservador de la seva pròpia vida, encara que aquest comportament el privi de l'oportunitat de gaudir dels plaers més intensos del menjar introduïts en la seva cultura, tant en qualitat com en quantitat. Un consumidor conservador, protagonista d'una de les paradoxes del risc, que sol tenir un comportament més segur des d'un punt de vista objectiu i que tendeix a demanar més mesures de seguretat. Els consumidors que senten més el risc de menjar són els que tenen menys marge d'acceptació del risc i, per tant, els que menys probabilitats tenen de ser víctimes d'un àpat. Aquells que s’alimenten habitualment de manera més segura són els que prenen més precaucions quan fan l'àpat. A l'altre pol, hi trobem el comensal refractari o indisciplinat, encara que també es podria caracteritzar des d'una perspectiva positiva: aquell que és fidel als seus hàbits i plaers. Deixant l'addicció relativament de banda, ja que entraríem en un altre debat sobre l' "addicció cultural», ens tro-

6. La perplexitat sorgeix quan aquest marc d'informació experta, que actua com a fons de les decisions dels consumidors, mostra contradiccions o es troba en crisi. 
bem davant d'un model de comportament que s'assemblaria, en part, al del fumador empedreït, que alguna cosa ha sentit dels efectes nocius del consum de tabac, però que prefereix continuar vinculat a aquesta font que li genera plaer. No obstant això, la comparació ha de fer-se amb molt de compte, ja que la diferència es troba en el fet que una bona part dels comensals han estat educats en la bondat d'alguns àpats que ara són criticats pels seus efectes futurs. El que abans dominava per la bona valoració en la seva cultura, fins i tot per les «qualitats morals» que tenia, i estava vinculat al que estava bé, ara només és valorat parcialment com a plat simbòlic, amb una condemna afegida en clau de risc potencial per a la salut. En aquest cas, estaríem parlant d'un individu plenament integrat en la seva cultura, que comprèn des de la cultura tradicional i rural dels grans tiberis, originàriament vinculats a un gran esforç físic, fins a l'accelerada cultura del consumidor urbà de fast food (Grefe i altres, 1988; Ritzer, 1996). La teoria de l'aprenentatge ens diu que sempre costa renunciar a allò que hem après dins l'entorn familiar i domèstic, als referents immediats. Per aquest motiu, malgrat la creixent tendència a menjar "col-lectivament» (restaurants, menjadors de col-legi, de la feina, etc.), el rol de la família continua sent molt important per constituir la cultura alimentària.

Per tal que aquest risc a llarg termini sigui acceptat per un individu modern, s'ha de nodrir especialment de fonts de confiança mediàtiques. Els mitjans de comunicació constitueixen la principal font de confiança a l'hora de decidir quina dieta es vol seguir. El que diuen els mitjans sobre el "menjar sa», sobretot quan l'emissor té un prestigi cientificomèdic, sembla que s'estigui convertint en el nou dogma del consumidor a la recerca d'una espècie de vida terrenal eterna. D’aquesta manera, es fa palesa la proliferació de programes de ràdio i de televisió dedicats a aquest tema, la de blocs a Internet, així com d'un ampli espai a les prestatgeries de les llibreries dedicat a textos de nutrició i títols firmats per metges reconeguts de les especialitats mèdiques més variades. Es tracta d'una confiança que prové dels especialistes, que es difon a través dels mitjans de comunicació i que és producte de la divisió del treball social, que genera especialistes funcionals i dispositius de confiança i autoritat per a cada funció.

En la funció del menjar, en la seva vinculació amb la salut i en l'acceptació del risc a llarg termini, la professió mèdica hi ocupa un lloc dominant. Les ciències dures tenen el seu camp en les dietes. Com més dures i especialitzades són, més bona acollida reben. Per aquest motiu, es pot parlar d'una confiança orgànica, si ens permeteu el joc de paraules, en un doble sentit: per l'especialització dels emissors de confiança en determinats òrgans corporals i, el que és més important, perquè, des de la perspectiva del consumidor, aquest necessita articular-les, integrar-les orgànicament, a partir de la seva especialització i, per tant, dels avantatges i de les limitacions derivats de la divisió de què són producte.

La confiança familiar estava arrelada difusament en la tradició cultural comunitària però fortament «incorporada» en els comensals, amb la qual cosa es convertia en un cos que reaccionava ostensiblement davant de la presència 
de l'aliment estrany o simplement nou. La confiança orgànica apareix més vinculada amb el present i el futur, possiblement seguint la lògica de la recerca de la novetat dels seus canals, els mitjans de comunicació. Es necessària la confiança en noves dietes o, almenys, una renovació més àmplia de la confiança en algunes de les existents. Una concreció de la confiança amb noms i cognoms - els dels especialistes que firmen els llibres o la intervenció en els programes de ràdio i de televisió- $\mathrm{i}$, sobretot, amb títols acadèmics, encara que siguin de creació tan recent com el de nutricionista. El fet que hagi aparegut, indica un grau més elevat d'especialització en la matèria.

\section{La confiança i les crisis alimentàries}

Tal com s'ha exposat més amunt, la divisió del treball social, font de la solidaritat orgànica de Durkheim, és també la font de la nostra confiança orgànica. Però, com molt bé apuntava el sociòleg clàssic francès, la pròpia divisió del treball era el que s'amagava darrere de la percepció d'anomia social que tant preocupava. Tornant al nostre camp alimentari, cal reconèixer, dins l'enorme divisió del treball social i la intervenció de diferents agents (Freudenburg, 1993), que va des de la producció dels queviures fins a la prestatgeria de la botiga o del supermercat, una de les fonts de risc en l'alimentació, sobretot si es té en compte que cadascuna de les parts que hi intervenen procura intensificar els seus beneficis.

Ens trobem, així, en un context social en el qual les fonts de risc potencials són més grans $\mathrm{i}$, per tant, les amenaces sobre la confiança també podrien ser més evidents. Però, alhora, la necessària confiança general per gestionar aquest risc, també general en el camp de l'alimentació, igualment pot considerar-se més gran. Potser això explica el retorn relativament ràpid a la confiança general després de cadascuna de les crisis alimentàries. Pot dir-se, doncs, que hi ha una confiança general en el sistema. En el sistema social i, per tant, en el sistema d'institucions o, el que pot considerar-se el mateix, la confiança orgànica reposa sobre un sistema de confiança.

Un sistema de confiança es concreta en institucions, però reposa sobre una consciència social. De la mateixa manera que Durkheim (1982: 96) recorre al concepte de "consciència col-lectiva», aquí es fa el mateix amb el de «sistema de confiança», com a consciència col.lectiva de certa seguretat.

S'han elaborat molts treballs, especialment des de la psicologia social, enfocats a la definició dels components o factors de la confiança. Treballs on hi ha una aproximació, més o menys indirecta, a les fonts de confiança (competència, objectivitat, eficiència, imparcialitat, consistència, experiència, coneixement tècnic, compromís, etc.). Aspectes que, tot i que provenen de diferents investigacions, poden vincular-se entre ells. Tanmateix, aquí es destaca el resultat de la confiança com a producte interrelacionat de diferents agents destinats a generar justament això, confiança. N'hi hauria de general en el camp alimentari produïda per diferents agents, la qual cosa conformaria un sistema de confiança, més que no pas una confiança atribuïda a cadascun dels agents 
o elements d'aquest sistema. Quan el sistema de confiança cau, cauen tots els agents de confiança, encara que no ho facin de la mateixa manera. Cada agent de confiança (productors, marques, distribuïdors, científics, administracions estatals, mitjans de comunicació, experts) es troba en un entramat comú, cadascú amb la seva especificitat, cadascú amb la seva funció. És un sistema que viu un sisme en cada crisi, i això fa que alguns d'aquests agents (Administració estatal, mitjans de comunicació i científics) ascendeixi a una posició superior als altres a mesura que projecten en un grau més elevat la institucionalització d'interessos més generals o de menys interessos particulars. Així, als científics se'ls dota de més capital de confiança a mesura que se'ls desproveeix d'interessos particulars previs.

Després de la presentació dels dos models de risc alimentari, pot establirse una apreciació en clau de principi: el domini del risc a llarg termini dins l'acceptació del risc alimentari modern condueix a una extensió general de l'acceptació del risc alimentari. Una extensió de l'acceptació en dos sentits: en l'augment de productes nous per a la cultura occidental, on es troba el nucli del model modern, i en la pròpia percepció del risc. Augment que porta a una recerca més gran de fonts de confiança, a la seva extensió i a l'extensió de la varietat d'aquestes, de forma que així sorgeix la competència potencial, quan no hi ha contradicció, entre elles. Així, assistim a l'espectacle on unes dietes es presenten com a millors $i$, sobretot, més eficaces que les altres. Una eficàcia que, alhora, comporta especialització: per a la salut en els diferents trams d'edat, ocupació i trajectòria vital; per a l'equilibri del pes; per evitar el colesterol; per al cervell i els músculs, però potser no tant per a... Aquesta especialització es tradueix en una amplitud diversa de la percepció de les amenaces i, per tant, en el marge que ha de tenir en compte l'acceptació del risc. El que és bo per a un fi o un objectiu, pot ser que no ho sigui tant per a un altre fi o, fins i tot, per a una altra funció o un altre òrgan corporal, i així successivament. D'aquesta manera, difícilment podem parlar d'una situació de falta de normes, d'anomia en el consum alimentari modern o, com Fischler recull en un atractiu neologisme, de gastronomia (Fischler, 1979). Al contrari, s'assisteix a la coexistència de diferents normes especialitzades i, de vegades, contradictòries, la qual cosa no deixa de generar incerteses en el consumidor (Díaz Méndez i Gómez Benito, 2005).

L'individu es troba, doncs, perceptivament més lligat al risc alimentari i té consciència de l'amplitud que abasta. Així, quan les pràctiques relacionades amb la seguretat alimentària — controls, inspeccions, seguiments epidemiològics, identificació i traçat dels aliments, etc. - són objectivament més àmplies $i$ aquesta seguretat ha assolit uns nivells desconeguts fins ara, la consciència de risc per part del consumidor és comparativament més gran.

La demanda de fonts de confiança és també superior i, alhora, cadascuna d'aquestes fonts disposa, si més no, d'una mínima línia de sospita, que només la pròpia necessitat de confiança venç amb dificultat. Aquesta situació pot explicar un curiós procés que es produeix durant les denominades «crisis alimentàries»: 
- La sensació de seguretat general queda trencada. Fins i tot el conjunt de les fonts de confiança, que se suposa que estan orgànicament reforçades, entren en crisi. Els consumidors i receptors dels missatges sobre risc i seguretat es troben, llavors, més atents a les contradiccions: el que diu l'autoritat administrativa, davant el que diuen els diversos científics, tendents als debats i la contradicció entre si, i el que diuen els diversos agents especialitzats (productors, distribuïdors, etc.). És com si calgués una recomposició del sistema de totes aquestes fonts d'experts, de garantia. És per això que, durant un període que sol ser curt, marcat per la capacitat de la crisi de continuar sent material rellevant en els mitjans de comunicació, tots els agents $i$ totes les fonts de confiança entren en una espècie de competència, augmenten l'enfrontament i fan evident la lògica autònoma de cadascuna de les fonts de confiança potencials.

- La necessitat social de confiança porta a un restabliment de l'equilibri orgànic fiable. La referida competència entre les diferents fonts de confiança acaba quan s'aconsegueix un nou equilibri o sistema de garantia, que comporta una coordinació renovada. Es possible que algun d'aquests agents obtingui una posició millor, mentre que d'altres quedin una mica tocats.

La millor manera d'exposar aquest procés és concretant-lo en crisis conegudes. Potser pocs recorden la denominada crisi de «l'oli de colza», ubicada exclusivament a Espanya. Ja fa trenta anys que es va produir i les víctimes supervivents encara en pateixen les terribles conseqüències. Doncs bé, en el moment de l'alarma inicial «natural», cadascuna de les diferents fonts de confiança es van preocupar principalment de responsabilitzar les altres: productors del sector de l'oli en donaven la culpa a autoritats públiques, aquestes a distribuïdors, etc. Fins i tot les pròpies víctimes, la gran majoria de les quals provenia de classes populars, van ser acusades de caure en l'atracció d'uns preus massa barats per tractar-se d'un producte fiable i d'haver-lo adquirit en canals de distribució dels quals no es podien refiar (venda ambulant de forma predominant, tot i que no únicament). Hi va haver un primer moment de declaracions i manifestacions més confuses que no pas aclaridores. Durant la cursa de cada font de confiança per «salvar el seu lloc», es va arribar a expressions públiques caricaturesques ${ }^{7}$. Amb la identificació - i detenció posterior - dels empresaris implicats en l'enverinament massiu, el sistema de confiança va recuperar cert equilibri. Ara bé, va experimentar canvis importants, com ara el guany del valor de garantia dels productes (oli d'oliva), de les marques i dels canals de distribució (botigues de «tota la vida») coneguts. En certa manera i durant un període, es va produir una regressió a un sistema de fonts fiables amb relació al producte que podria considerarse anterior, si no fos pel paper adquirit per la marca. De fet, un dels agents prin-

7. Com la del ministre de Sanitat que, davant de les càmeres de televisió, dibuixava imaginàriament la presència i la trajectòria d'una «bestioleta». Una compareixença pública que ha d'estar en totes les antologies dels cursos ara estesos i dels màsters sobre comunicació del risc. Almenys, per evitar el ridícul en un tema tan dolorós. 
cipalment perjudicats en aquell moment, encara que li va servir per prendre una àmplia consciència de la rellevància del control relatiu que havia de tenir sobre la distribució, va ser el de les cooperatives de productors d'oli d'oliva, que, malgrat que tinguessin denominació d'origen altament reconeguda, podien estar mancades de marca arrelada en el sistema de confiança.

La crisi de les «vaques boges», que tots tenim encara en la memòria i que també va tenir gravíssimes conseqüències directes sobre vides humanes (i occidentals, caldria afegir-hi, a diferència d'altres crisis més directes, com ara la relativa a la grip aviària, tècnicament coneguda com a SAR), també pot servir-nos com a exemple del procés que s'observa. La crisi sorgeix quan l'epidèmia de l'encefalopatia espongiforme bovina passa a l'ésser humà, perquè abans ja s'havia reconegut en el bestiar. Salten les discussions sobre les causes de la situació i la centralització de la responsabilitat, en especial, sobre la falta de mesures preses anteriorment, quan ja n'hi havia sospites. Entremig, declaracions de tot tipus, amb evidents matisos entre si, entorn del punt central del risc. Així, arribem al debat sobre la conveniència d'ingerir «costelles amb os» i les repetides compareixences públiques de responsables polítics, que intenten regenerar la confiança en el producte amb tiberis periodístics carnis, metges, veterinaris, epidemiòlegs, etc. És a dir, diferents especialistes i no sempre amb la mateixa explicació de les causes i, per tant, diverses maneres de fer front a la crisi. Més enllà d'acusacions a agents i fins i tot a persones concretes, l'acusat és el conjunt del sistema de confiança. És més, durant les últimes crisis relacionades amb la producció animal —encefalopatia espongiforme bovina, grip aviària, febre aftosa, anisakiosi-, no apareixen culpables amb noms. L'acusat és un sistema de producció, una civilització, una manera de fer, però, sobretot, un sistema fiable. La seguretat en l'alimentació arriba a situar-se entre els principals problemes dels espanyols durant un mes, segons les enquestes del Centre d'Investigacions Sociològiques ${ }^{8}$. El sector productor de la carn de boví s'espera el pitjor. Tanmateix, a poc a poc, les opinions dissonants van desapareixent. Convergeixen i es reforcen les manifestacions de científics, sector i autoritats. Es torna a un sistema de confiança en el qual es fixen una altra vegada els papers de cadascú. $\mathrm{Al}$ mes següent, la proporció d'espanyols que assenyala la seguretat en l'alimentació com a problema és estadísticament insignificant. Al cap de poc temps, es recupera el consum de boví. Ara bé, el retorn de la confiança necessària es produeix mitjançant certes transformacions en les posicions dins del sistema de representació de les diferents fonts. La indústria, en el moment que domina en la percepció de la confiança com a procés que «no toca» el producte, manté el paper guanyat durant un esforç de màrqueting $\mathrm{i}$ una adaptació al consumidor durant els vint-i-cinc anys anteriors9. Així, la marca esdevé el nom que, per protegir-se a si mateixa, protegeix el consumidor

8. Un seguiment de l'evolució de l'opinió pública sobre això es pot trobar a Callejo (2001).

9. Durant la dècada de 1970 , la desconfiança es va dirigir principalment contra la indústria agroalimentària, vinculada a una imposició de gustos homogenis i massius en els consumidors, que acabava amb la seva cultura culinària. 
Quadre 2. Procés durant les crisis alimentàries

\section{Aparició}

- Notícies en el sistema de mitjans de comunicació de massa.

- Alarmes periodístiques.

- Angoixa difusa de l'opinió pública.

- Declaracions confuses dels responsables polítics. Respostes a partir del propi sistema de mitjans de comunicació, tant d'autoritats com de productors i distribuïdors.

- Contradiccions entre agents i especialistes de seguretat.

- Opinions dividides entre científics i experts: discussions sobre les causes.

Crisi en el sistema de confiança

- Enfrontament entre agents de seguretat.

- Regressió a fonts de confiança més tradicionals.

- Identificació dels productes amb risc.

- La majoria dels aliments apareixen amb potencial amenaçador, per la qual cosa s'assumeix, en una perspectiva fatalista, què cal menjar. Fase que Fischler denomina d' «autoconsumació».

- Recerca de culpables o d'agents culpables de la crisi. Un problema de control de la seguretat n'acaba sent la causa principal.

- Identificació dels responsables de la crisi.

- Es posen en evidència les connexions i la complexitat dels sistemes de producció i distribució, de manera que tendeix a desplaçar-se el nucli de risc cap a l'infinit, perquè s'hi involucren productes molt diferents.

- Les enquestes, com a instruments que tenen la funció de certificar l'opinió pública, registren una elevada preocupació per part dels ciutadans.

- Crisi general del sistema social.

i adquireix més valor. Encara que, al sector carni, la marca hi té un paper menys important, sembla que augmenta el valor en el conjunt del consum alimentari. Finalment, el mitjancer proper, l'expert pròxim, com ara el «carnisser de tota la vida», intensifica el seu paper com a font de confiança. Tanmateix, $\mathrm{i}$ encara que sembli paradoxal, la producció i la distribució «artesanal», el producte del "poble aliè» ${ }^{10}$, quan apareix als ulls del consumidor com a "fora de control», comença a generar desconfiança ${ }^{11}$. La distribució i els processos de manipulació que no tenen una forta vigilància i, sobretot, que són sense nom, apareixen com els principals perjudicats en la reconfiguració del sistema. Fent un esforç de síntesi, amb l'ajut del treball de Fischler (1998), que analitza la crisi de les "vaques boges", poden establir-se les fases següents en una crisi on es veu el procés que segueixen: aparició, creixement i final (quadre 2).

10. La carn i altres productes frescos amb origen al «mateix poble» apareixen sota una representació semblant a la de l'expert immediat (carnisser del barri), com si el procés de producció es dugués a terme sota control del propi consumidor.

11. Els resultats d'una investigació empírica sobre la confiança del consumidor, dins d'una investigació més àmplia sobre els hàbits alimentaris dirigida per Cecilia Díaz, pot trobarse a Callejo (2005). 
Quadre 2. Procés durant les crisis alimentàries (continuació)

\section{Sortida de la crisi}

- A través de l'autoritat governamental, es veu la necessitat d'introduir un nou codi de conducta voluntària en la producció.

- Crides d'ajuda per part dels productors, a causa de les pèrdues econòmiques. Compensacions als productors nacionals per aquestes pèrdues, baix compromís d'assumpció de nous codis de conducta per al conjunt del sector directament afectat.

- Reforç de les manifestacions dels agents i dels especialistes.

- Nova coordinació entre agents de seguretat.

- Campanyes publicitàries fomentades i firmades per autoritats i productors per tornar la confiança al consumidor. Campanyes per contrarestar temors.

- Establiment de nous plans i reformes de conducta, amb la implicació de tots els sectors, inclosos els consumidors. S'estableix una espècie de pacte de seguretat. Noves reglamentacions, amb inclusió de mesures sancionadores notables, dirigides a productors i distribuïdors.

\section{Recuperació del sistema de confiança}

- Dissipació de l'interès pel tema per part dels mitjans de comunicació.

- Institucionalització de la renovació del sistema de confiança amb la creació de nous departaments administratius, observatoris específics o direccions generals particulars de seguretat alimentària.

- Ràpid oblit per part de l'opinió pública. Es parla, així, de la «síndrome de l'oblit» en les crisis alimentàries.

- Durant molt temps després, i a porta tancada, continuarà el debat científic sobre les veritables causes de la crisi.

És clar, el procés de restabliment de la confiança requereix temps. El procés de tota relació de confiança sempre requereix temps (Luhmann, 1979: 10), però les nostres societats sembla que estan destinades a restablir-se de forma inequívoca per seguir sent modernes. De les dues crisis esmentades, el més important és ressaltar com, després del període d'histèria, es torna a un nou equilibri del sistema de fonts de confiança d'una manera més o menys ràpida. Es recupera la confiança en el rol de cada agent, en la seva especialitat, i, d'aquesta forma, es recupera un funcionament general. La confiança orgànica contribueix al funcionament de la societat, més enllà del propi funcionament biològic de l'individu, la qual cosa li redueix l'ansietat derivada del risc de menjar.

Durant el període inicial de la crisi, s'imposen, en la percepció del consumidor, més aviat les conseqüències potencials més extremes derivades del fet d'haver tastat l'aliment, és a dir, la mort o la malaltia greu, i no pas el risc estadístic mínim del contagi o la malaltia, que sol ser el tema central d'autoritats administratives i de científics. Però, llevat que es tracti d'aliments relativament secundaris, com passava amb l'oli de colza, la recuperació de la confiança esdevé necessària. Per fer-ho, cadascuna de les fonts fiables realitza diferents movi- 
ments. Després de cada crisi, s'intenta compensar, amb noves capacitats de control, el debilitament que solen experimentar les autoritats administratives, ja que són les últimes dipositàries de la garantia col-lectiva en el control dels aliments abans que arribin a l'estómac del consumidor. S'elaboren reglaments i lleis que intensifiquen les possibilitats de controlar els aliments, així com sancions i penes per als transgressors de les mesures adoptades. En aquest aspecte, cal fer notar el creixement continu del dret del consum, tant en l'àmbit nacional com en el de la legislació comunitària de la Unió Europea. Un augment que, a més, sol anar reforçat amb vincles directes al dret penal. La nova reorganització del sistema de confiança té tendència a reforçar els dispositius sancionadors, tant en la duresa dels càstigs com en la certesa de l'aplicació. Es tracta d'impedir la rendibilitat de la infracció en un context dominat per la lògica econòmica dels beneficis.

Les fonts de confiança que pertanyen al mercat també segueixen uns passos concrets. Inicialment, ho fan amb declaracions tranquil.litzadores de les associacions corresponents. Més endavant, d'una manera més particularitzada, cada marca o mitjancer específic fa un sobreesforç per recuperar la confiança dels seus consumidors. Els uns, a través del màrqueting, i els altres, a través del contacte directe amb el client, la qual cosa fa més palesa la precaució presa i el seguiment de les normes i de les reglamentacions establertes per les autoritats administratives. Després de cada crisi, es produeix un arranjament relacional. Els discursos dels científics també passen per un cert moment convulsiu. Al principi, al costat de les veus institucionals -instituts científics de referència (CSIC, a Espanya, per exemple), direccions generals científiques, etc.- , s'alcen veus d'altres experts científics, que, atesa l'actualitat de l'assumpte, troben un ampli ressò en els mitjans de comunicació. Sembla que s'assisteix a l'espectacle d'un debat que havia estat portat discretament darrere les bambolines de la ciència. Gairebé tots els que ocupen un lloc rellevant com a experts en algun dels camps científics, directament o indirectament afectats, es veuen obligats a participar-hi, fins que s'imposa una línia de consens dominant, gairebé sempre favorable a les institucions.

D'aquesta manera, a poc a poc, tots els col-lectius, dins el seu paper i amb la seva lògica autònoma, van confluint les accions i els passos d'uns i d'altres. Més ben dit, subratllant cadascú el seu paper, amb les seves limitacions, s'arriba a un moviment articulat $i$, el que és més important amb vista a guanyar la confiança del consumidor, a promeses i a programes d'actuació conjunta. Es produeix una nova concertació. Per exemple, es creen observatoris, comissions de seguiment, etc. on estiguin representats tots els agents del sector. Així, de mica en mica, es recupera una seguretat general i es va donant fi a l'angoixa del consumidor. Després de cada crisi, té lloc un augment del procés de diferenciació del sistema de confiança, de la seva constitució com a sistema. D'una banda, es produeix una diferenciació interna: cada un dels elements del sistema de confiança destaca quina és la seva funció davant els altres elements. D’altra banda, es realitza una diferenciació externa a mesura que aquest sistema renovat de confiança es va fent més visible, amb la qual cosa es converteix en un 
nou nucli de la confiança general i, sobretot, nega unes altres fonts alienes de confiança ${ }^{12}$.

El sistema de confiança renovat reinverteix el procés. D'aquesta forma, el cercle viciós de l'angoixa pel risc, que succeeix tot esclat crític com a representació acumulativa de fonts de risc, esdevé un cercle virtuós en el qual s'estabilitzen les expectatives, amb la qual cosa es converteix en la via per la qual s'absorbeix la incertesa. Com indica Luhmann (1998: 119), l'absorció d'incertesa es dóna mitjançant l'estabilització de les expectatives i no mitjançant l'estabilització de la mateixa conducta. Amb els nous passos seguits, es tendeix a crear expectatives i a estabilitzar-ne. Es recrea una nova situació de fiabilitat, que, com indica Borricaud (1982: 270), es troba lluny de ser una situació de creença cega (o fanàtica), ja que, en el menjar, mai no hi ha un excés de confiança. D'altra banda, el dubte, en una societat de risc que demana constantment seguretat, sempre hi serà present. Però es tindran prou garanties per menjar amb tranquil.litat.

\section{Conclusions}

La seguretat s'ha convertit en una de les obsessions de les societats occidentals, en una característica que també s'ha projectat sobre una pràctica tan sensible al risc com l'alimentació. Si menjar sempre ha tingut una part de risc i, per tant, fer una queixalada ha comportat acceptar-lo, dins del que s'ha considerat el model modern de risc alimentari, aquesta acceptació s'ha estès i s'ha ampliat. Quan, almenys a Occident, semblaven superades les crisis alimentàries relatives a l'escassetat i quan els controls públics sobre el menjar semblen més rigorosos i continuats que mai, la demanda de seguretat alimentària per part del consumidor és superior. Quan, tenint en compte un senzill indicador com l'esperança de vida, en el qual té una repercussió especial el tipus de dieta, s’assoleixen els màxims nivells, perquè l'angoixa de l'individu ressorgeix amb força davant de la presència de l'amenaça més mínima, tot sembla convertir-se en una palanca per a la desconfiança, quelcom que queda accentuat en cada crisi, $i$, tanmateix, es recupera una confiança quotidiana.

L'augment d'aquesta recerca de seguretat $i$, per tant, la mateixa extensió de l'acceptació del risc, té la raó principal en el domini del perill alimentari a llarg termini, una circumstància clarament moderna. Es tracta de l'essència i el producte de la modernitat, és a dir, l'establiment d'estratègies vitals per a la construcció de futur, el paper de la prevenció, etc. Un risc a llarg termini que té el focus principal en l'elecció de la dieta. Una elecció viscuda individualment, amb la qual pot arribar a establir-se una identitat social (vegetarians, tradicionals, etc.). Com a risc, requereix fonts de confiança per prendre decisions. És aquí on també s'estableix una diferència respecte al model de gestió del risc

12. Com assenyala Luhmann (1998), un sistema és un sistema perquè es diferencia sistemàticament del que no és sistema. 
que s'ha considerat tradicional. Davant una confiança basada en les tradicions familiars, que té per font principal la pròpia cultura i les referències immediates, es configura una fiabilitat que s'alimenta de diferents fonts especialitzades i autònomes.

A la segona part del treball, s'ha intentat reflectir sintèticament com es qüestiona i es reorganitza el sistema de confiança amb alguna crisi alimentària important. Dos moments polars d'un procés, amb diferents fases, destinats a tornar la confiança necessària al consumidor, però que, en cap cas, no farà que la seva elecció de dieta, de consum continuat d'un conjunt d'aliments, es converteixi en una experiència de risc zero. Tota acceptació del risc exigeix fonts de confiança. Tota font de confiança és un dispositiu a què cal recórrer, però, almenys en el consum alimentari, no n'hi ha cap que estigui mancada de limitacions, sobretot en el procés d'especialització i divisió del treball. Només l'articulació equilibrada de les diferents fonts de confiança, relacionades les unes amb les altres, genera un context general de seguretat en el menjar. És el moment en què el sistema de fonts de confiança està concertat.

Finalment, i davant tota interpretació mecanicista, l'esforç de reorganització del sistema de confiança és directament proporcional a la violència adquirida per la crisi. Fort en el cas de les «vaques boges» o, amb anterioritat i al nostre país, de l'«oli de colza». Com va ocórrer amb la crisi de l'encefalopatia espongiforme bovina a la Gran Bretanya, pot arribar a ser un esforç col-lectiu que faci necessari fins i tot un canvi de govern.

\section{Referències bibliogràfiques}

BeCK, U. (1992). Risk Society: Towards a New Modernity. Londres: Sage.

BORRICAUD, F. (1982). «Sobre la noción de comunicación sociopolítica». A: LABARRIÈRE, J.-L. y otros. Teoría política y comunicación. Barcelona: Gedisa, 265-274.

Callejo, J. (2001). "Crisis de la encefalopatía espongiforme: huecos en el modelo social de consumo». Estudios sobre consumo, any XVI, 58, 47-60.

- (2005). «Seguridad alimentaria y confianza del consumidor». A: DÍAz MÉnDEZ, C. (coord.). ¿Cómo comemos? Cambios en los comportamientos alimentarios de los españoles. Madrid: Fundamentos, 181-219.

Díaz Méndez, C. y Gómez Benito, C. (2005). «Una aproximación a las teorías y los debates actuales en torno a la alimentación contemporánea». A: DíAZ MÉNDEZ, C. (coord.). ¿Cómo comemos? Cambios en los comportamientos alimentarios de los españoles. Madrid: Fundamentos, 23-50.

DoUGLAS, M. (1996). La aceptabilidad del riesgo según las ciencias sociales. Barcelona: Paidós.

DuRKHeIM, E. (1982). La división del trabajo social. Madrid: Akal.

Elias, N. (1989). El proceso de civilización. Mèxic: Fondo de Cultura Económica.

FisCHLER, C. (1979). «Gastronomie-nomie et gastro-anomie: sagesse du corp et crise bioculturelle de l'alimentation moderne». Comunications, 31, 189-210.

- (1995). El (h)omnivoro. Barcelona: Anagrama.

- (1998). "La maladie de la "valle folle"». A: Aplfelbaum, M. (dir.). Risque et peurs alimentaires. París: Odile-Jacob, 45-56. 
Flandrin, J.-L. (1998). «Risques et angoisses alimentaires avant le XIX ${ }^{\mathrm{e}}$ siècle». A: Aplfelbaum, M. (dir.). Risque et peurs alimentaires. París: Odile-Jacob, 113-123. FreudenburG, W. R. (1993). "Risk and Recreancy: Weber, the Division of Labor, and the Rationality of Risk Perceptions». Social Forces, juny, 71 (4), 909-932.

Giddens, A. (1990). Consecuencias de las modernidad. Madrid: Alianza.

Grefe, C.; Heller, P.; Herbst, M. y PATer, S. (1988). El imperio de la hamburguesa. Barcelona: Gedisa.

HARris, M. (1999). Bueno para comer. Madrid: Alianza.

Le Breton, D. (1995). La sociologie du risque. París: Métailié.

Luhmann, N. (1979). Trust and Power. Chichester: John Wiley \& Sons.

- (1992). Sociología del riesgo. Guadalajara (Mèxic): Universidad Iberoamericana i Universidad de Guadalajara.

- (1998). Sistemas sociales. Barcelona: Anthropos.

Malthus, T. R. (1990). Ensayo sobre el principio de la población. Madrid: Akal.

Ritzer, G. (1996). La Macdonalización de la sociedad. Barcelona: Gedisa.

Schlosser, E. (2003). Fast Food. Barcelona: Debolsillo.

Shallins, M. (1983). Economía de la Edad de Piedra. Madrid: Akal.

SMITH, A. (1983). Investigación de la naturaleza y causas de la riqueza de las naciones. Barcelona: Orbis.

WACQUANT, L. (2000). Las cárceles de la miseria. Madrid: Alianza. 